\title{
FUNGSI KOMUNIKASI
}

\author{
Lutfi Basit
}

Dosen

\begin{abstract}
Abstrak
Terdapat empat fungsi komunikasi adalah (1) menginformasikan (to inform):Yaitu memberikan informasi kepada masyarakat, memberitahukan kepada masyarakat mengenai peristiwa yang terjadi, ide atau pikiran dan tingkah laku orang lain, serta segala sesuatu yang disampaikan orang lain, ((2) Mendidik (to educate) yaitu : fungsi komunikasi sebagai sarana pendidikan. Melalui komunikasi, manusia dalam masyarakat dapat menyampaikan ide dan pikirannya kepada orang lain sehingga orang lain mendapatkan informasi dan ilmu pengetahuan. (3) Menghibur (to entertain) yaitu: Fungsi komunikasi selain menyampaikan pendidikan, dan mempengaruhi, komunikasi juga berfungsi untuk memberi hiburan atau menghibur orang lain. (4) Mempengaruhi (to influence) yaitu: fungsi mempengaruhi setiap individu yang berkomunikasi, tentunya berusaha saling mempengaruhi jalan pikiran komunikan dan lebih jauh lagi berusaha merubah sikap dan tingkah laku komunikan sesuai dengan apa yang diharapkan.
\end{abstract}

Kata Kunci: Fungsi, Komunikasi.

\section{A. Pendahuluan}

Dalam perspektif psikologi komunikasi, ada 4 tahap terjadinya proses komunikasi, yaitu sensasi, persepsi, memori dan berpikir (Jalaluddin Rahmat, Psikologi Komunikasi). Sensasi adalah proses ditangkapnya stimuli oleh indera manusia. Stimuli yang ditangkap oleh manusia itu kemudian diproses dan kemudian menjadi produk pesan komunikasi.Tanpa indera, maka manusia seperti terlepas dari dunia.Manusia diciptakan oleh Allah dengan perangkat yang memungkinkan manusia untuk menyerap informasi untuk memaksimalkan peran manusia sebagai khalifah (inni jaailun fil ardhi khalifah).Seorang khalifah haruslah menguasai informasi. Penguasaan informasi tersebut akan memudahkan untuk membangun komunikasi yang efektif.

Menurut Fisher (1986) ilmu komunikasi mencakup semua dan bersifat eklektif.Sifat eklektif ilmu komunikasi digambarkan oleh Wilbur Schramm (1963) sebagai jalan simpang yang ramai, semua disiplin ilmu melintasinya. Schramm membandingkan ilmu komunikasi dengan kota purba Babelh Dehre. Di kota itu para pengembara lewat, singgah, dan meneruskan perjalanan. Bekas persinggahan para pengembara tersebut menunjukkan keluasan ilmu komunikasi. (Wiryanto, $2004: 5$ )

Luasnya cakupan ilmu komunikasi tersebut juga nampak dari definisi komunikasi dari sudut pandang yang berbeda. Hovland mendefinisikan komunikasi sebagai proses 
dimana individu mentransmisikan stimulus untuk mengubah perilaku individu yang lain. (Hovland, $1948: 371$ ).

Everett M. Rogers dan Lawrence Kincaid menytakan bahwa komunikasi adalah suatu proses di mana dua orang atau lebih membentuk atau melakukan pertukaran infomrasi antara satu sama lain, yang pada gilirannya terjadi saling pengertian yang mendalam. (Rogers, 1981 $: 18)$

Bernard Berelson dan Gary A. Steiner menyampaikan komunikasi adalah transmisi informasi, gagasan, emosi, keterampilan dan sebagainya dengan menggunakan simbolsimbol, dan sebagainya.( Berelson Bernard, 1964 : 527)

Komunikasi dalam perspketif dakwah Islam juga memiliki fungsi-fungsi yang telah dipaparkan di atas.Fungsi-fungsi tersebut juga dapat ditelusuri dalam pesan-pesan komunikasi yang disampaikan Rasulullah dalam bentuk hadits.

\section{B. Hadits Yang Mengandung Fungsi Memberi Informasi}

Kata informasi berasal dari kata Perancis kuno informacion (tahun 1387) yang diambil dari bahasa latin informationem yang berarti "garis besar, konsep, ide".Informasi merupakan kata benda dari informare yang berarti aktivitas dalam "pengetahuan yang dikomunikasikan" (Online Etymology Dictionary).

Informasi adalah pesan (ucapan atau ekspresi) atau kumpulan pesan yang terdiri dari order sekuens dari simbol, atau makna yang dapat ditafsirkan dari pesan atau kumpulan pesan. Informasi adalah data yang telah diberi makna melalui konteks.Informasi bisa dikatakan sebagai pengetahuan yang didapatkan dari pembelajaran, pengalaman, atau instruksi (https://id.wikipedia.org).

Informasi memiliki ciri-ciri sebagai berikut:

a. Benar atau salah, dalam hal ini informasi berhubungan dengan kebenaran atau kesalahan terhadap kenyataan.

b. Baru, informasi harus benar-benar baru bagi si penerima.

c. Tambahan, informasi dapat pemperbarui atau memberikan perubahan terhadap informasi yang telah ada.

d. Korektif, informasi dapat digunakan untuk melakukan koreksi terhadap informasi sebelumnya yang salah atau kurang benar.

e. Penegas, informasi dapat mempertegas informasi yang telah ada sehingga keyakinan terhadap informasi semakin meningkat. 
Dengan merujuk kepada definisi dan ciri-ciri informasi di atas maka hadits-hadits berikut dapat dikategorikan sebagai hadits komunikasi dengan fungsi informasi.

1. Informasi tentang Kedudukan Ali bin Abi Thalib dan Sahabat Lain

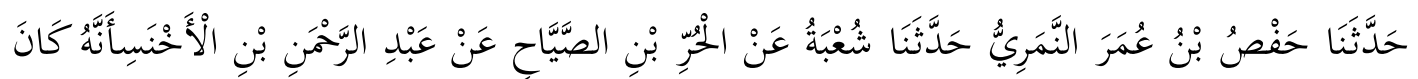

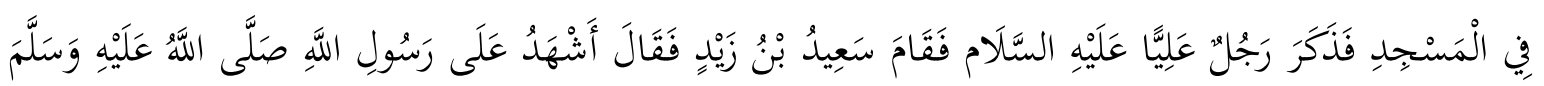

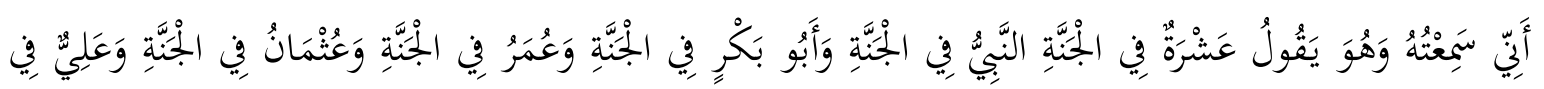

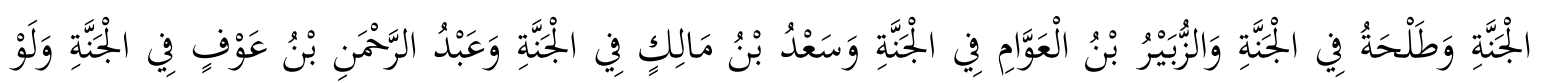

$$
\begin{aligned}
& \text { شِيْتُ لَسَمَّيْتُ الْعَاشِرَ قَالَ فَقَالُوا مَنْ هُوَ فَسَكَتَ قَالَ فَقَالُوا مَنْ هُوَ فَقَالَ هُوَ سَعِيدُ بْنُ زَيْدِ. }
\end{aligned}
$$

Telah menceritakan kepada kami Telah menceritakan kepada kami Hafsh bin Umar An Namari berkata: telah menceritakan kepada kami Syu'bah dari Al Hurri bin Ash Shayyah dari 'Abdurrahman Ibnul Akhnas bahwa ketika itu ia sedang berada di masjid, lalu ada seorang laki-laki menyebutkan tentang Ali, maka Sa'id bin Zaid berdiri dan berkata: Aku bersaksi atas Rasulullah shallallahu 'alaihi wa sallam bahwa aku mendengar beliau bersabda: "Ada sepuluh orang (akan) masuk surga (tanpa hisab) Nabi berada di surga, Abu Bakr berada di surga, Umar berada di surga, Utsman berada di surga, Ali berada di surga, Thalhah berada di surga, Az Zubair Ibnul Awwam berada di surga, Sa'd bin Malik berada di surga, 'Abdurrahman bin Auf berada di surga." (Sa'id bin Zaid berkata:) dan jika aku mau maka akan aku sebutkan yang kesepuluh." 'Abdurrahman berkata: "Orang-orang lalu bertanya: "Siapa orangnya?" Sa'id diam. 'Abdurrahman berkata: "Orang-orang bertanya lagi: "Siapa orangnya?" Sa'id menjawab: "Dia adalah Sa'id bin Zaid."

Hadits ini terdapat di buku Sunan Abu Dawud No. 4031.Menurut Muhammad Nashiruddin al Albani hadits ini berada derajat shahih. Dilihat dari sisi sanad maka Sa'id bin Zaid Amru bin Naufal adalah dari kalangan sahabat Nabi yang wafat pada tahun $51 \mathrm{H}$. Hadits dari Said juga diriwayatkan oleh Bukhori sebanyak 8 hadits, Muslim 11, Abu Dawud 6, Tirmidzi 9, Nasa'I 4, Ibnu Majah 5, Ahmad 32, Darimi 1, sedangkan Malik tidak meriwayatkan 1 hadtis pun dari Sa'id bin Ziad. Abdur Rahman bin Al Akhnas adalah Tabi'in kalangan pertengahan yang hidup di Kufah.Hadits-haditsnya juga diriwayatkan oleh Abu 
Dawud, Tirmidzi dan Ahmad. Ibu Hibban menyebutkan dalam 'ats tsiqaat, sedangkan Ibnu Hajar al 'Asqalani memberikan komentar mastuur.

Hurr bin Ash Shayyah seperti Abdurrahman adalah Tabi'in kalangan pertengahan yang hidup di Kufah.Hadits-haditnya diriwayatkan oleh Abu Dawud, Tarmidzi, Nasa'i dan Ahmad. Ulama Yahya bin Ma'in, An Nasa'i dan Adz Dzahabi menyebutnya tsiqah. Sedangkan Abu Hatim Ar Rozy mengomentarinya sebagai tsiqah shalihul hadits.

Syu'bah bin Al Hajjaj bin Al Warad hidup di Bashrah dari kalangan tabi'ut tabi'in kalangan tua yang wafat pada $160 \mathrm{H}$. Haditsnya cukup banyak diriwayatkan oleh 8 imam selain Malik. Beberapa ulama memberikan komentar terhadap Su'bah bin Al Hajjaj. Al 'Ajli menyebutnya tsiqah tsabat, Ibnu Sad menyebutkan tsiqah ma'mun, Abu Daud memuji bahwa tidak ada seorangpun yang lebih baik haditsnya dari padanya, Ats Tauri menyebutnya amirul mukminin fil hadits, Ibnu Hajar Al Atsqalani menyebutnya tsiqah hafidz sedangkan Adz Dzahabi mengomentari sebagai tsabat hujjah.

Hafsh bin 'Umar bin Al Harits bin Sakhbarah merupakan tabi'ul atba' kalangan tua yang hidup di Bashrah dan wafat pada $225 \mathrm{H}$. Abu Dawud paling banyak meriwayatkan hadits dari Hafdsh bin 'Umar, disusul Bukhari, Nasa'i, Tirmidzi, dan Darimi, sedangkan imam yang lain tidak meriwayatkan hadits darinya. Yahya bin Ma'in dan Adz Dzahabi memujinya sebagai tsiqah, Abu Hatim Ar Rozy menyebtunya shaduuq mutqin dan Ahmad bin Hambal menyebutnya tsiqah tsiqah mutqin.

Ditinjau dari matan hadits yang diawali dengan seseorang yang membicarakan tentang Ali bin Abi Thalib, maka sahabat yang lain memberikan informasi tentang Ali yang mungkin belum diketahui oleh sahabat yang membicarakan tentang Ali tersebut. Informasi bahwa Ali adalah sahabat yang disebut Rasulullah SAW akan masuk surga, di samping informasi tambahan tentang sahabat-sahabat lain yang juga akan masuk surga.

Informasi yang dikandung oleh hadits ini, dengan menyebutkan langsung nama-nama para sahabat, juga mengindikasikan penegasan tentang keutamaan sahabat tersebut dalam aspek yang lain, seperti kepemimpinan. Ditinjau dari aspek komuniakasi, maka pernyataan Nabi tersebut dapat ditafsirkan sebagai pembentukan opinion leader di tengah masyarakat muslim. Opinion leader adalah sebuah konsep yang muncul dari teori aliran dua-langkah komunikasi yang dikemukakan oleh Paul Lazarsfeld dan Elihu Katz. Dalam proses komunikasi opinion leader ini muncul dalam teori two-step flow of communication. (Siagian, 2011 : 72-81). 


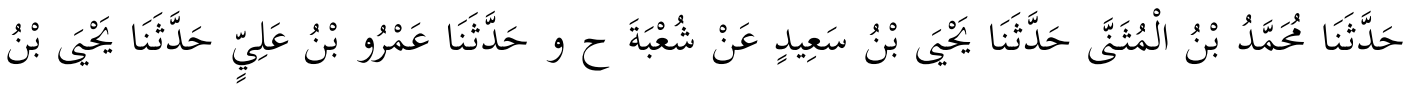

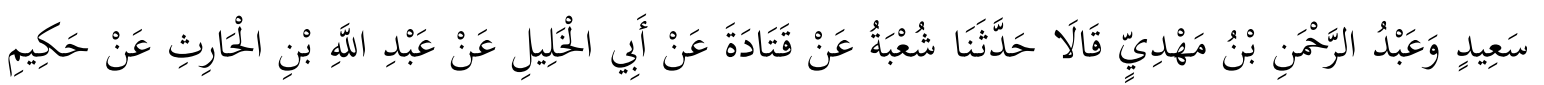

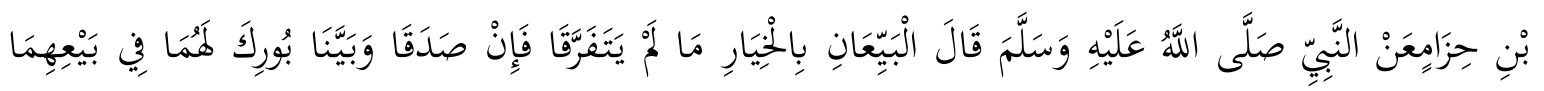

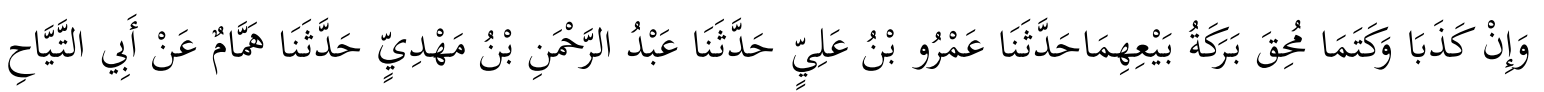

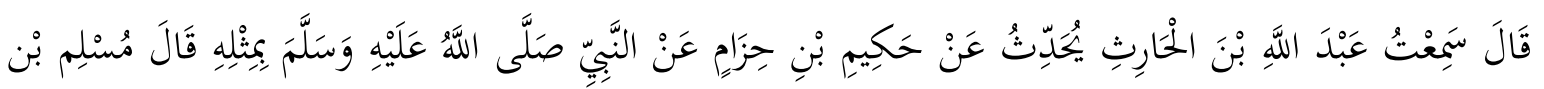

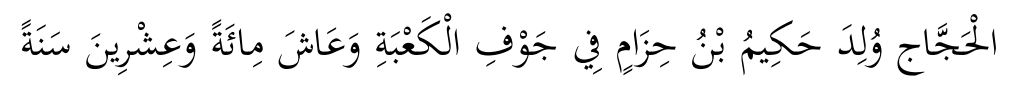

Shahih Muslim 2825: Telah menceritakan kepada kami Muhammad bin Al Mutsanna telah menceritakan kepada kami Yahya bin Sa'id dari Syu'bah. Dan dari jalur lain, telah menceritakan kepada kami Amru bin Ali telah menceritakan kepada kami Yahya bin Sa'id dan Abdurrahman bin Mahdi keduanya berkata: Telah menceritakan kepada kami Syu'bah dari Qatadah dari Abu Al Khalil dari Abdullah bin Al Harits dari Hakim bin Hizam dari Nabi Shallallu 'alaihi wa sallam, beliau bersabda: "Orang yang bertransaksi jual beli berhak khiyar (memilih) selama keduanya belum berpisah. Jika keduanya jujur dan terbuka, maka keduanya akan mendapatkan keberkahan dalam jual beli, tapi jika keduanya berdusta dan tidak terbuka, maka keberkahan jual beli antara keduanya akan hilang." Telah menceritakan kepada kami Amru bin Ali telah menceritakan kepada kami Abdurrahman bin Mahdi telah menceritakan kepada kami Hammam dari Abu At Tayyah dia berkata: Saya mendengar Abdullah bin Al Harits telah menceritakan dari Hakim bin Hizam dari Nabi Shallallu 'alaihi wa sallam, seperti hadits di atas, Muslim bin Hajjaj berkata: Hakim bin Hizam dilahirkan di dalam Ka'bah, dan dia hidup selama seratus dua puluh tahun.

Hadits ini adalah hadits shahih menurut ijtima' ulama. Sanadnya bisa ditelusuri sampai Hakim bin Hizam bin Khuwailid dari kalangan sahabat yang hidup di Marur Rawd, wafat pada 54 H. Dari Sembilan imam hadits, hanya Malik yang tidak meriwayatkan darinya.

Hadits ini memberikan informasi bahwa hak-hak harus dilindungi dalam transaksi bisnis dan perdagangan.Hak tersebut diantaranya adalah hak untuk mengetahui dengan jelas 
kondisi barang/komiditi yang menjadi objek jual beli.Keterbukaan antara orang-orang yang terlibat di dalam transaksi bisnis sangat penting untuk menjamin hasil yang memuaskan kedua belah pihak.

Dalam perspektif komunikasi keterbukaan antara komunikator dan komunikan dalam proses komunikasi sangat penting. Menurut pandangan Joseph A. DeVito bahwa salah satu karakteristik komunikasi efektif adalah keterbukaan, kualitas keterbukaan komunikasi setidaknya menunjukkan tiga aspek, yaitu: 1) saling terbuka dalam berkomunikasi sehingga terjadi pertukaran informasi, yakni komunikator bersedia menyampaikan secara lengkap informasi yang seharusnya disampaikan kepada komunikan. 2) berkomunikasi untuk bereaksi secara jujur, yakni komunikator mengungkapkan secara spontan reaksinya (tidak dibuat-buat) kepada komunikan. 3) komunikator bertanggung jawab terhadap apa yang diungkapkan.(DeVito, $2011: 259$ )

\section{Fungsi Informasi tentang Ghibah}

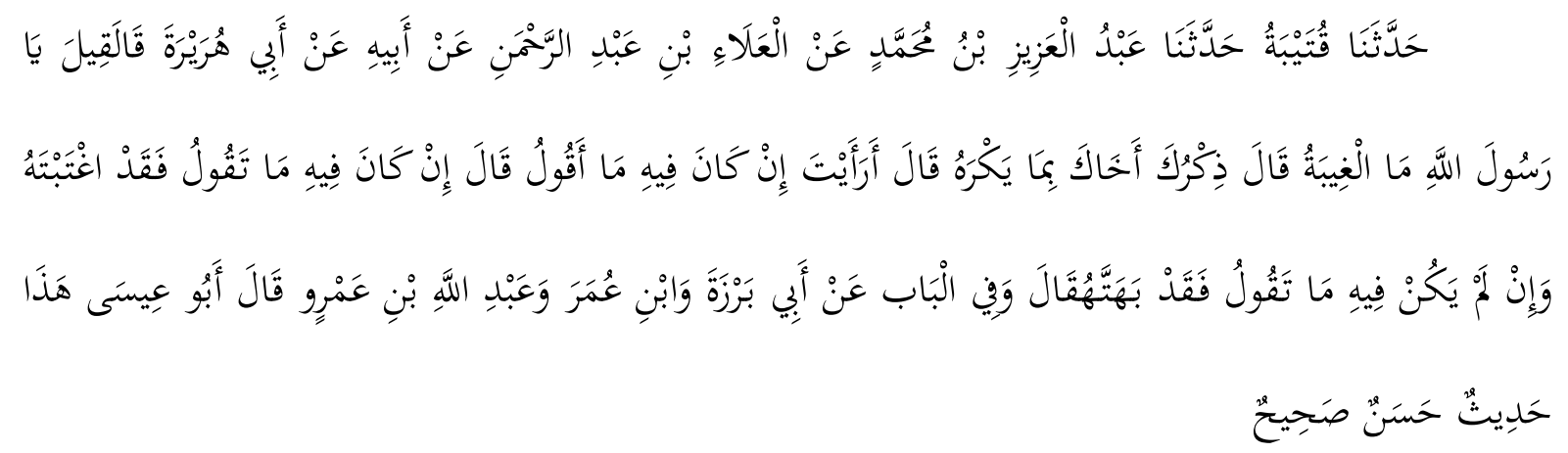

Sunan Tirmidzi 1857: Telah menceritakan kepada kami Qutaibah, telah menceritakan kepada kami Abdul Aziz bin Muhammad dari Al Ala` bin Abdurrahman dari bapaknya dari Abu Hurairah ia berkata: Ditanyakan kepada Rasulullah, "Wahai Rasulullah, apakah ghibah itu?" beliau menjawab: "Kamu menyebutkan tentang temanmu dengan sesuatu yang ia benci." Ia bertanya lagi, "Bagaimana sekiranya apa yang kukatakan memang benar?" Beliau menjawab: "Jika memang apa yang kamu katakan itu benar, maka sungguh kamu telah menggibahnya, namun jika apa yang kamu katakan itu tidak benar, maka sungguh kamu telah berdusta." Hadits semakna juga diriwayatkan dari Abu Bazrah, Ibnu Umar dan Abdullah bin Amr. Abu Isa berkata: Ini adalah hadits hasan shahih. 
Hadits Shahih menurut Muhammad Nashiruddin al Albani. Dilihat dari sanadnya maka kita mendapatkan Abdur Rahman bin Shakhr dari kalangan sahabat yang hidup di Madinah dan wafat pada $57 \mathrm{H}$. haditsnya diriwiyatkan oleh ulama 9. Abdur Rahmad bin Yaqub adalah kalangan tabi'in kalangan pertengahan dan hidup di Madinah. Bukhori tidak meriwayatkan haditsnya.Komentar ulama sangat positif. Al 'Ajli, Ibnu Hajar al 'Asqalani dan Adz Dzahabi menilai tsiqah, sedangkan An Nasa'i memberikan komentar laisa bihi ba's dan Ibnu Hibban menyampaikan disebutkan dalam 'ats tsiqaat.

Al 'Alaa' bin 'Abdurrahman bin Ya'qub merupakan tabi'in kalangan biasa, hidup di Madinah dan wafat tahun 132H. Sama dengan Abdur Rahmad bin Yaqub, tidak ada satupun haditsnya diriwayatkan oleh Bukhori. Ibnu 'Adi mengatakan bahwa dia tidak memiliki masalah, sama dengan Nasa'I yang menyampaikan laisa bihi ba's. ibnu Hibban mentsiqahkannya. Abu Hatim Ar Rozy mengatakan shalih, perawi tsiqah meriwatarkannya darinya dan aku menginginkan hadtisnya. Tirmidzi menyebutnya tsiqah menurut ahli hadits, sedangkan Ahmad bin Hambal mengatakan bahwa di tsiqah, dan tidak pernah terdengar seseorang menyebutnya dengan keburukan.

Abdul 'Aziz bin Muhammad bin 'Ubaid bin Abi 'Ubaid dari kalangan tabi'ut tabi'in kalangan pertengahan, hidaup di Madinah dan wafat pada $187 \mathrm{H}$. Malik tidak pernah meriwayatkan haditsnya. Meskipun Abu Zur'ah menilainya sebagai buruf hafalan, tetapi ulama yang lain memberikan komentar yang positif, seperti Yahya bin Ma'in mengatakan laisa bihi ba's, Ibnu HIbban menyampaikan Abdul 'Aziz disebutkan dalam ats tsiqaat, sedangkan Al 'Ajli mengkatogorikannya sebagai tsiqah.

Qutaibah bin Sa'id bin Jamil bin Tharif bin 'Abdullah dari tabi'ul atba' kalangan tua yang hidup di Himsh dan wafat pada tahun $240 \mathrm{H}$. Malik dan Darimi tidak meriwayatkan hadits darinya. Ulama seperti Abu Hatim, An Nasa'I dan Yahya bin Ma'in mengatakan tsiqah dan Ibnu Hajar al 'Asqalani menyebutnya tsiqah tsabat.

Hadits ini bersifat informatif bisa dilihat dari kandungan hadits ini yang dimulai dari pertanyaan seseorang yang tidak mengetahui tentang ghibah.Atas pertanyaan tersebut Rasullullah memberikan informasi tentang maksud ghibah.

\section{Fungsi Informasi tentang Nasab Asal Usul Bangsa-Bangsa}




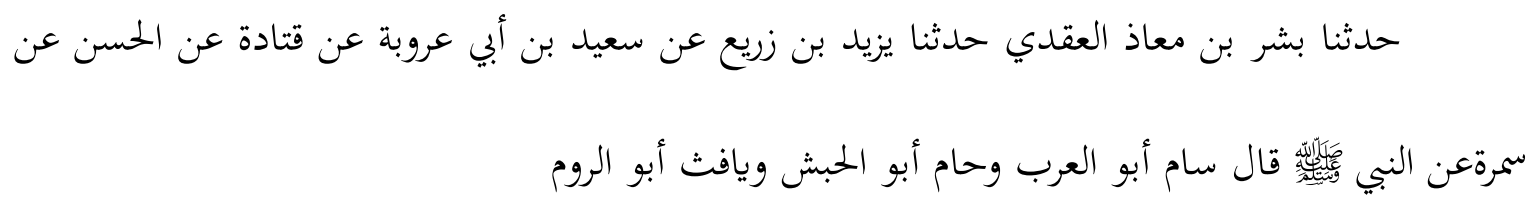

Sunan Tirmidzi 3155: Telah menceritakan kepada kami Bisyr bin Mu'adz Al Aqadi telah menceritakan kepada kami Yazid bin Zurai' dari Sa'id bin Abu Urubah dari Qatadah dari Al Hasan dari Samurah dari nabi Shallallahu 'alaihi wa Salam, beliau bersabda: "Sam bapak bangsa arab, Ham bapak bangsa Habasy (Etiopia, Afrika) dan Yafits bapak bangsa Romawi (Eropa)."

Di dalam Sunan Tirmidzi Kitab Tafsir Al Qur'an Bab Di antara surat Shaffat. Menurut Muhammad Nashiruddin Al Albani hadits ini pada derajat dhoif (lemah).

Dalam hadits lain masih di Sunan Tirmidzi:

$$
\begin{aligned}
& \text { حدثنا بشر بن معاذ العقدي بصري حدثنا يزيد بن زريع عن سعيد بن أبي عروبة عن قتادة عن } \\
& \text { الحسن عن سمرة بن جندبأن رسول الله } \\
& \text { هذا حديث حسن ويقال يافث ويافت ويفت }
\end{aligned}
$$

Sunan Tirmidzi 3866: Telah menceritakan kepada kami Bisyr bin Mu'adz Al 'aqadi Bashri telah menceritakan kepada kami Yazid bin Zurai' dari Sa'id bin Abu 'Arubah dari Qatadah dari Al Hasan dari Samurah bin Jundab bahwa Rasulullah shallallahu 'alaihi wa sallam bersabda:

"Sam (nama orang) adalah nenek moyangnya orang-orang Arab, dan Yafits adalah nenek moyangnya orang-orang Romawi, sedangkan Ham adalah nenek moyangnya orangorang Habasyah."

Abu Isa berkata: "Hadits ini adalah hadits hasan." Yafits disebut juga dengan Yafit atau Yafat."

Hadits ini disebutkan juga di dalam Musnad Ahmad pada hadits No. 19240, 19241 dan 19255 dengan matan sedikit yang berbeda.

\section{Hadits Yang Mengandung Fungsi Mendidik}

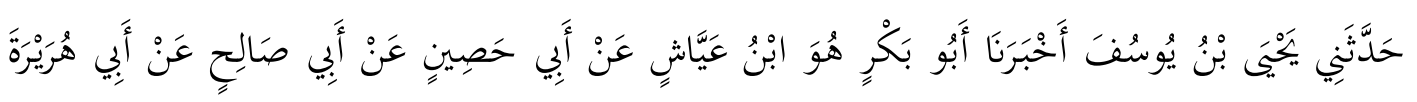

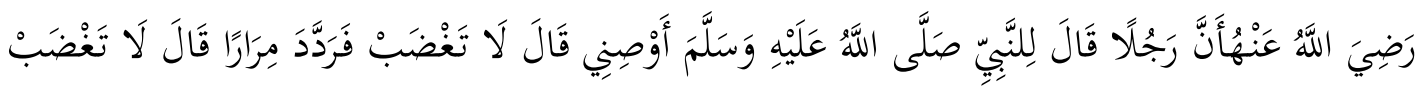


Shahih Bukhari 5651: Telah menceritakan kepadaku Yahya bin Yusuf telah mengabarkan kepada kami Abu Bakr yaitu Ibnu Ayyasy dari Abu Hashin dari Abu Shalih dari Abu Hurairah radliallahu 'anhu bahwa seorang laki-laki berkata kepada Nabi shallallahu 'alaihi wa sallam: "Berilah aku wasiat?" beliau bersabda: "Janganlah kamu marah." Laki-laki itu mengulangi kata-katanya, beliau tetap bersabda: "Janganlah kamu marah."

Hadits yang diriwayatkan oleh Bukhari ini adalah hadits shahih menurut ijtima' ulama. Dari sisi sanad bisa ditelusuri sampai Abdur Rahman bin Shakhr yang dikenal dengan Abu Hurairah, dari kalangan shahabat yang hidup di Madinah dan wafat pada $57 \mathrm{H}$. Semua imam hadits yang 9 meriwayatkan hadits-hadits Abu Hurairah. Kemudian setelah itu Dzakwan dari tabi'in kalangan pertengahan, hidup di Madinah dan wafat pada $101 \mathrm{H}$. Ulama Abu Zur'ah menyebutkan mustaqiimul hadits dan ulama yang lain menyebutnya tsiqah. Setelah itu Utsman bin 'Ashim bin Hushain, seorang tabi'in kalangan biasa yang hidup di kufah pada tahun $128 \mathrm{H}$. Dari 9 imam hadits, hanya malik yang tidak meriwayatkan. Ulama seperti Adz Dzahabi dan Yahya bin Ma'in dan lainnya menyebutkan tsiqah. Sanad selanjutnya Abu Bakar bin 'Ayyasy bin Salim, tabi'ut tabi'in kalangan tua yang hidup di Kufah dan wafat pada tahun 193 H. Imam Muslim dan Imam Malik tidak meriwayatkan hadits darinya. Ibnu Hajar al 'Asqalani menilainya maqbuul faadil. Kemudian Yahya bin Yusuf bin Abi Karimah, tabi'ul alba' kalangan tua, tinggal di Baghdad dan wafat pada 225 H. Hanya Imam Bukhari dan Ibnu Majah dari 9 imam yang meriwayatkan hadits darinya. Abu Hatim memberikan komentar bahwa Yahya adalah shaduuq, sedangkan ulama yang lain seperti Abu Zur'ah dan lainnya menyebutnya tsiqah.

Dalam hadits ini ada dua aspek penting yang berkaitan dengan mendidik.Aspek pertama menyangkut tujuan mendidik dan metode mendidik.Salah satu tujuan mendidik adalah pembentukan karakter.Dalam Islam, marah terbagi dua, marah yang terpuji dan marah yang tercela. Namun jelas yang dimaksud oleh hadits tersebut adalah marah negatif karena nabi menggunakan huruf 'laalin nahyi,' sehingga dampak yang ditimbulkan adalah negatif, tidak menyenangkan dan menyusahkan.Kata-kakta mutiara Arab ini menjadi gambaran berbahayanya rasa marah yang negative "awal kemarahan adalah gila, dan akhirnya adalah penyesalan."

Dalam Kamus Besar Bahasa Indonesia,pengertian marah adalah perasaan tidak senang karenadiperlakukan tidak sepantasnya. Albin mengungkapkan bahwa rasa marah merupakan emosi yang sangat sukar bagi setiap orang, baik dalam halmenerima ataupun 
untuk mengungkapkannya. Rasa marah menunjukkan bahwa suasana perasaan tersinggung oleh seseorang atau sesuatu sudah tidak baik

Karakter yang ingin dibangun nabi adalah karakter pemaaf hal itu bisa dilihat bagaimana nabi yang bersikap memaafkan orang-orang yang membenci, mengganggu atau menyakitinya. Fathu makkah adalah bukti kolosal yang otentik bagaimana karakter bangsa yang ingin dibangun oleh rasulullah SAW. Hal ini sebangun dan linear dengan misi kebian Muhammad untuk menyempurnakan akhlaqul karimah.

Aspek Kedua adalah metode mendidik.Di antara metode mendidik yang banyak dilakukan adalah memberikan pengulangan (disampaikan atau dilakukan berulang-ulang) agar peserta didik dapat mengingat dan memahami dengan baik.dalam perspektif psikologi komunikasi, termasuk stimuli yang memiliki sifat menonjol untuk menarik perhatian, di samping gerakan, intensitas stimuli, dan kebaruan.

Hal-hal yang disajikan berkali-kali bila disertai dengan sedikit variasi, akan menarik perhatian. Di sini unsur “ familiarity”( yang sudah kita kenal) berpadu dengan unsur "novelty" (yang baru kita kenal). Perulangan juga mengandung unsur sugesti: memengaruhi bawah sadar kita. Bukan hanya pemasang iklan, yang menpopulerkan produk dengan mengulang-ulang atau slogan-slogan, tetapi juga kaum politisi memanfaatkan prinsip pengulangan. Emil Dofivat (1968), tokoh aliran publisistik Jerman, bahkan menyebut perulangan sebagai satu di antara tiga prinsip penting dalam menaklukan massa.

Hadits lain yang memiliki efek mendidik dari sudut pandang komunikasi adalah:

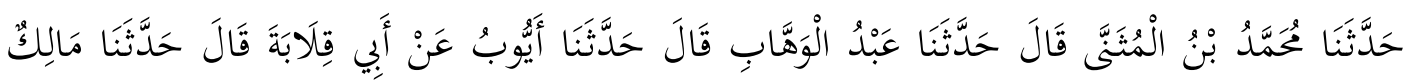

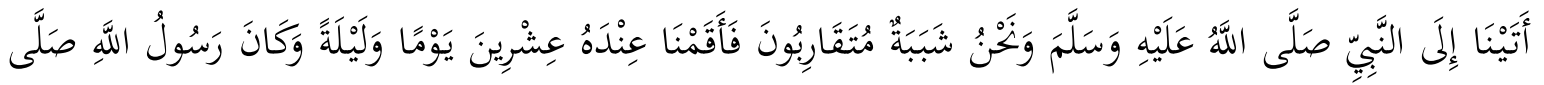

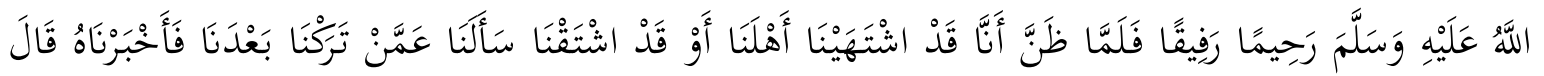

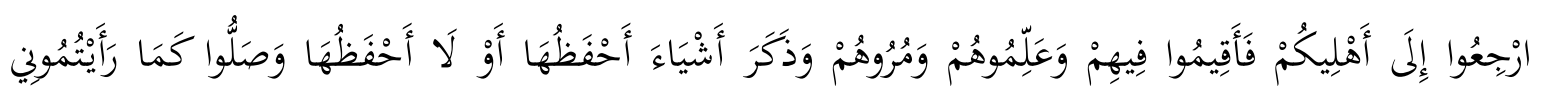

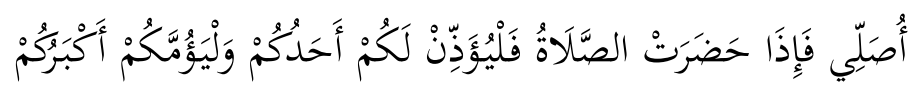

Shahih Bukhari 595: Telah menceritakan kepada kami Muhammad bin Al Mutsanna berkata: telah menceritakan kepada kami 'Abdul Wahhab berkata: telah menceritakan kepada kami Ayyub dari Abu Qilabah berkata: telah menceritakan kepada kami Malik:

Kami datang menemui Nabi shallallahu 'alaihi wa sallam, saat itu kami adalah para pemuda yang usianya sebaya.Maka kami tinggal bersama beliau selama dua puluh hari dua 
puluh malam.Beliau adalah seorang yang sangat penuh kasih dan lembut.Ketika beliau menganggap bahwa kami telah ingin, atau merindukan keluarga kami, beliau bertanya kepada kami tentang orang yang kami tinggalkan.Maka kami pun mengabarkannya kepada beliau. Kemudian beliau bersabda: "Kembalilah kepada keluarga kalian dan tinggallah bersama mereka, ajarilah mereka dan perintahkan (untuk shalat)." Lantas beliau menyebutkan sesuatu yang aku pernah ingat lalu lupa. Beliau mengatakan: "Shalatlah kalian seperti kalian melihat aku shalat. Maka jika waktu shalat sudah tiba, hendaklah salah seorang dari kalian mengumandangkan adzan, dan hendaklah yang menjadi Imam adalah yang paling tua di antara kalian."

Hadits ini dapat ditemukan di shahih Bukhari No. 595.Selain di Shahih Bukhari, juga dimuat di Sunan Darimi, Sunan Daruquthni, Shahih Ibn Khuzaimah, Shaih Ibn Hibban, dan Musnad Syafi'i.Hadits ini adalah hadits shahih menurut ijtima' ulama.Runutan sanadnya tidak perlu diragukan lagi.

Hadits ini penuh dengan fi'lul amri (kata kerja perintah).Di antara perintah yang ada di dalam hadits ini adalah perintah untuk sholat sesuai dengan sholat Nabi.Faktor utama dalam mendidik adalah uswah (keteladanan).Dengan kalimat sholatlah seperti Aku sholat adalah perintah untuk meneladani Rasulullah.Dalan prespektif komunikasi Nabi mengambil posisi sebagai komunikator dan sahabat sebagai komunikan.Jika komunikator memiliki karakter yang kredibel, maka pesan yang disampaikan sangat berpotensi mampu memengaruhi komunikan pada sisi kognitif, afektif, dan konatif.

Haditis lain yang memiliki fungsi mendidik adalah:

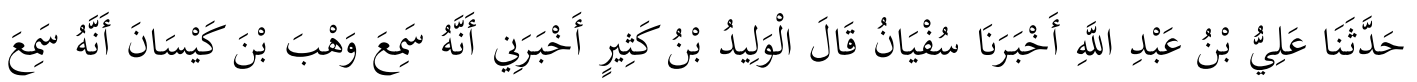

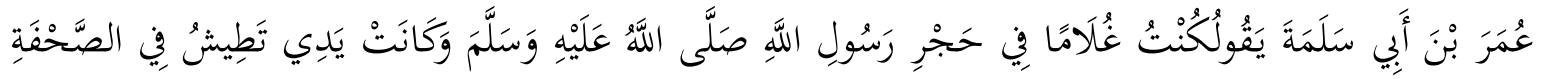

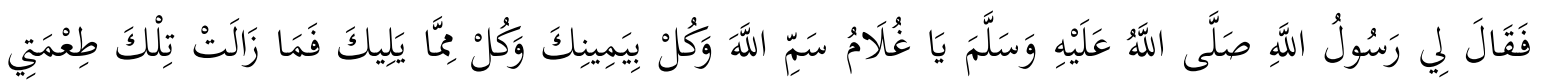

Shahih Bukhari 4957: Telah menceritakan kepada kami Ali bin Abdullah Telah mengabarkan kepada kami Sufyan ia berkata: Al Walid bin Katsir Telah mengabarkan kepadaku, bahwa ia mendengar Wahb bin Kaisan bahwa ia mendengar Umar bin Abu Salamah berkata: 
Waktu aku masih kecil dan berada di bawah asuhan Rasulullah shallallahu 'alaihi wa sallam, tanganku berseliweran di nampan saat makan. Maka Rasulullah shallallahu 'alaihi wasallam bersabda: "Wahai Ghulam, bacalah Bismilillah, makanlah dengan tangan kananmu dan makanlah makanan yang ada di hadapanmu." Maka seperti itulah gaya makanku setelah itu.

Hadits shahih menurut ijma' ulama, juga dimuat di Shahih Muslim, Sunan Tirmidzi, Sunan Abu Dawud, Sunan Darimi, dan Musnad Ahmad.Sanadnya adalah orang-orang yang tsiqah menurut catatan ulama.

Hadits ini mendidik bagaimana cara makan, pendidikan yang dimulai dari anak-anak. Periode anak merupakan periode perkembangan yang spesial karena memiliki kebutuhan psikologis, pendidikan, serta fisik yang khas. Perkembangan pada periode anak akan berpengaruh pada perkembangan masa-masa selanjutnya, bahkan gangguan yang terjadi pada masa dewasa dapat dirunut ke sumber permasalahannya, yang berasal dari masa kanakkanak. Jika anak sejak usia dini sudah diberikan pemahaman untuk menumbuhkembangkan sifat-sifat terpuji (mahmûdah) dan menghilangkan sifat-sifat tercela (mazmûmah), maka akan terbangun karakter yang baik bagi masa depannya.

Karakter adalah bagian dari membangun jiwa manusia, karakter yang baik tidak akan muncul tanpa diawali dengan penjiwaan terhadap karakter tersebut. Dari penjiwaan terhadap karakter akan memunculkan perilaku baik. Perilaku baik tidak akan muncul dengan tiba-tiba tanpa melalui proses pendidikan. Seseorang bersikap diawali dari mengenal yang baik, kemudian membiasakannya dan melatihnya terus menerus sehingga menjadi kepribadiannya. Ketika itu telah menjadi bagian dari pribadinya maka ia telah berbentuk karakter.(Daulay, $2014: 184)$

\section{Fungsi Menghibur}

Menghibur dalam Kamus Besar Bahasa Indonesia didefinisikan sebagai menyenangkan dan menyejukkan hati yang susah.

$$
\begin{aligned}
& \text { حدثنا زهير بن حرب وإسحق بن إبراهيم جميعا عن جرير قال زهير حدثنا جرير عن منصور عن } \\
& \text { إبراهيم عن الأسود قال دخل شباب من قريش على عائشة وهي بمنى وهم يضحكون فقالت ما يضحككم } \\
& \text { قالوا فلان خر على طنب فسطاط فكادت عنقه أو عينه أن تذهب فقالت لا تضحكوا فإنيسمت رسول الله } \\
& \text { 管 }
\end{aligned}
$$


Shahih Muslim 4664: Telah menceritakan kepada kami Zuhair bin Harb dan Ishaq bin Ibrahim seluruhnya dari Jarir. Zuhair berkata: Telah menceritakan kepada kami Jarir dari Manshur dari Ibrahim dari Al Aswad dia berkata: "Pada suatu hari, seorang pemuda Quraisy berkunjung kepada Aisyah, istri Rasulullah, ketika ia sedang berada di Mina. Kebetulan saat itu para sahabat sedang tertawa, hingga Aisyah merasa heran dan sekaligus bertanya: 'Mengapa kalian tertawa? ' Mereka menjawab: 'Si fulan jatuh menimpa tali kemah hingga Iehernya (atau matanya) hampir lepas.' Aisyah berkata: 'Janganlah kalian tertawa terbahakbahak! Karena sesungguhnya aku pernah mendengar Rasulullah shallallahu 'alaihi wa sallam bersabda: 'Tidaklah seorang muslim tertusuk duri atau yang Iebih kecil dari itu, melainkan akan ditulis baginya satu derajat dan akan dihapus satu kesalahannya.'

Hadits ini tercantum di Kitab Berbuat Baik, Menyambut Silaturrahmi, dan Adab.Bab seorang mukmin mendapat pahala karena musibah.Hadits bisa juga ditemukan di Shahih Bukhari, Sunan Nasa'i, Musnad Ahmad, Sunan Daruquthni.Sanadnya dalam semua tingkatan dikomentari oleh para ulama sebagai tsiqah, shaduuq dan Alhafidz.

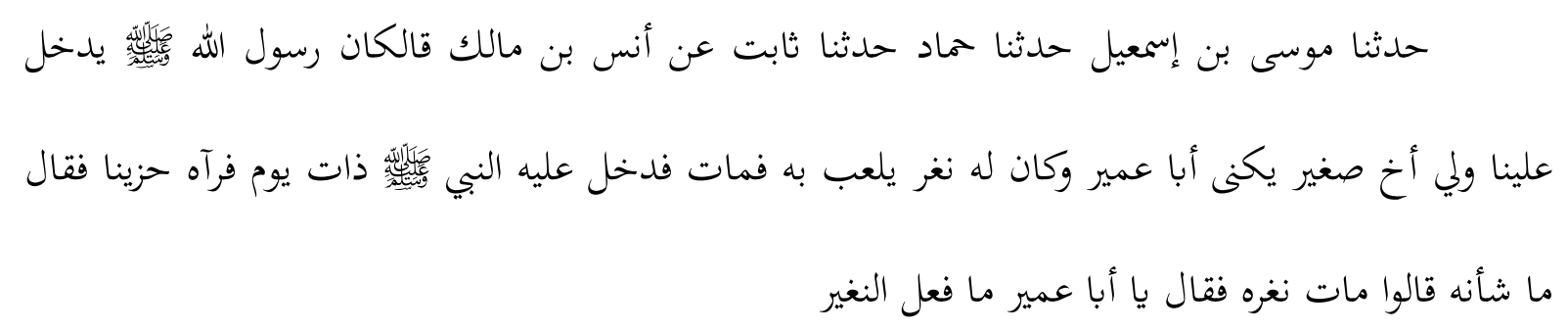

Sunan Abu Daud 4318: Telah menceritakan kepada kami Musa bin Isma'il berkata: telah menceritakan kepada kami Hammad berkata: telah menceritakan kepada kami Tsabit dari Anas bin Malik ia berkata:

"Suatu kali Rasulullah shallallahu 'alaihi wa sallam datang kepada kami, sementara kami mempunyai adik kecil yang dijuluki Abu Umair. Burung kecil miliknya yang biasa ia ajak main bersama mati. Lalu suatu hari Nabi shallallahu 'alaihi wa sallam masuk dan menemuinya sedang bersedih, beliau bertanya: "Apa yang sedang terjadi dengannya?" orangorang menjawab: "Burung kecilnya mati." Beliau lantas bersabda: "Wahai Abu Umair, apa yang sedang dilakukan oleh burung kecilmu?"

Shaih menurut Muhammad Nashiruddin Al Albani. Menurut catatan ulama, sanadnya adalah tsiqah, hanya 1 sanadnya, Hammad bin Salamah bin Dinar, seorang tabi'ut tabi' in kalangan pertengahan, Ibnu Hibban memberikan komentar bahwa Hammad diperselisihkan statusnya sebagai sahabat. 
Dilihat dari sudut pandang fungsi komunikiasi, hadits ini memiliki fungsi menghibur. Ketika seseorang bersedih, kemudian datang seseorang yang dimuliakan dan dihormati, dan menunjukkan rasa empati kepada orang yang sedang bersedih, maka orang yang bersedih tersebut akan terhibur dan senang karena merasakan menjadi istimewa dengan datangnya seorang yang istimewa dan tidak merasa sendiri di dalam menghadapi masalah karena orangorang di sekitarnya memberikan perhatian terhadap dirinya.

\section{E. Fungsi Komuniiasi Untuk Memengaruhi}

$$
\begin{aligned}
& \text { حدثنا يميى عن ثُمََّّ بن أبي إسماعيل حدثنا عبد الرحمن بن هلال العبسي قال قال جرير بن عبد الله قال } \\
& \text { رسول الله } \\
& \text { أجورهم شيء ولا يسن عبد سنة سوء يعمل بها من بعده إلا كان عليه وزرها ووزر من عمل بها لا ينقص من } \\
& \text { أوزارهم شيء قال وأتاه ناس من الأعراب فقالوا يا نبي الله يأتينا ناس من مصدقيك يظلمونا قال أرضوا مصدقكم } \\
& \text { وإن ظلم قال أرضوا مصدقكم قال جرير فما صدر عني مصدق منذ سمعتها من نبي الله }
\end{aligned}
$$

Musnad Ahmad 18410: Telah menceritakan kepada kami Yahya dari Muhammad bin Abu Isma'il Telah menceritakan kepada kami Abdurrahman bin Hilal Al Absi ia berkata: Jarir bin Abdullah berkata: Rasulullah shallallahu 'alaihi wa sallam bersabda: "Tidaklah seorang hamba merintis (kebiasaan) yang baik, sehingga kebiasaan itu diamalkan oleh orang setelahnya, kecuali baginya adalah pahala seperti pahala orang yang mengerjakannya dengan tanpa mengurangi dari pahala mereka sedikit pun. Dan tidaklah seorang hamba membuat kebiasaan yang buruk, kemudian kebiasaan itu diamalkan setelahnya, kecuali dosanya akan dibebankan ke atasnya, dan baginya dosa seperti dosa orang yang melakukannya dengan tidak mengurangi dari dosa mereka sedikiti pun." Maka orang-orang dari kalangan A'rab pun mendatangi beliau seraya berkata: "Wahai Nabiyullah, amil (pengelola zakat) mu, telah mendatangi kami, dan ia telah berbuat zhalim terhadap kami." Beliau bersabda: "Berikanlah kepadanya (apa yang menjadi kewajiban kalian) dan bersikap baiklah kepadanya, meskipun ia bersikap zhalim." Jarir berkata: "Semenjak saya mendengarnya dari Nabi shallallahu 'alaihi wa sallam, maka tidaklah Mushaddiq (amil zakat, pengelola zakat) pergi dari sisiku, kecuali ia dalam keadaan ridla." 
Pesan yang disampaikan Rasullullahi SAW dalam hadits ini ada sebuah metode persuasive untuk memengaruhi orang laing. Metode ini paling banyak digunakan untuk membujuk (to persuade) orang sehingga secara tidak sadar mengikuti keinginan komunikator yang menyampaikan bujukan.Dengan metode persuasi, seseorang atau sekelompok orang tidak merasa bahwa perubahan dalam dirinya adalah akibat pengaruh dari luar.Dia yakin bahwa dorongan merubah sikap, pendapat atau perilakunya memang sudah lama ada dalam dirinya. Salah satu cara dalam melakukan komunikasi persuasive adalah teknik ganjaran (pay-of technique) adalah kegiatan untuk memengaruhi orang lain dengan cara mengimingimingi hal yang menguntungkan atau yang menjanjikan harapan tertentu. teknik ini sering dipertentangkan dengan teknik pebangkitan rasa takut (fear arousing technique), yakni caracara yang bersifat menaku-nakuti atau menggambarkan konsekuensi yang buruk.

Dengan alasan yang serupa, hadits di berikut juga menunjukkan efek komunikasi untuk memengaruhi komunikan:

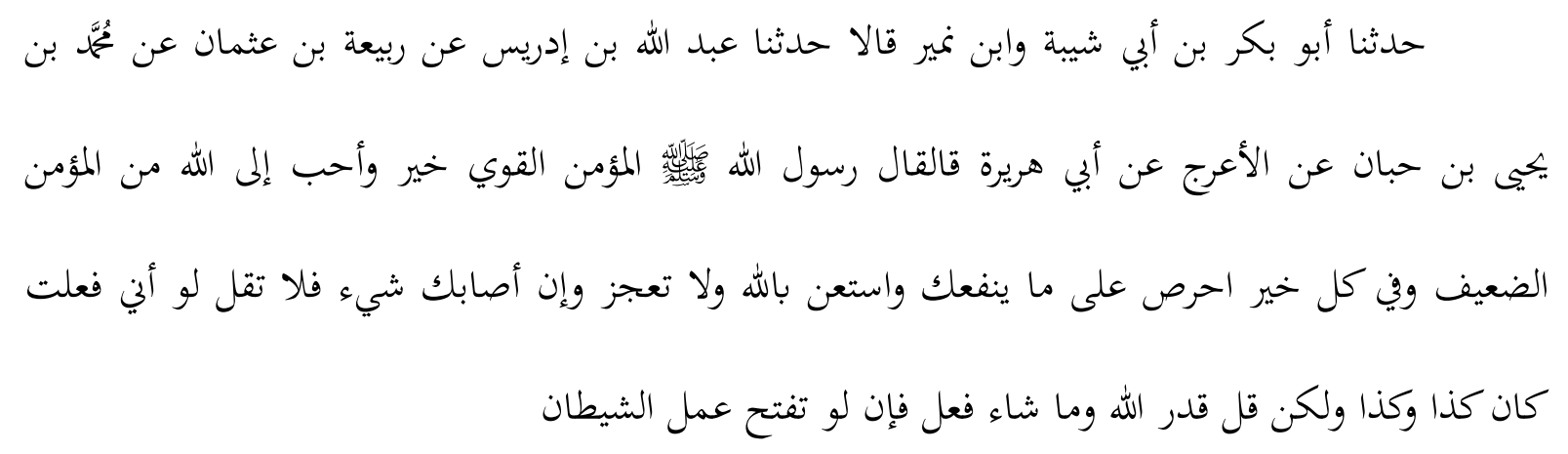

Shahih Muslim 4816: Telah menceritakan kepada kami Abu Bakr bin Abu Syaibah dan Ibnu Numair mereka berdua berkata: telah menceritakan kepada kami 'Abdullah bin Idris dari Rabi'ah bin 'Utsman dari Muhammad bin Yahya bin Habban dari Al A'raj dari Abu Hurairah dia berkata: "Rasulullah shallallahu 'alaihi wa sallam bersabda: 'Orang mukmin yang kuat lebih baik dan lebih dicintai oleh Allah Subhanahu wa Ta 'ala daripada orang mukmin yang lemah. Pada masing-masing memang terdapat kebaikan. Capailah dengan sungguh-sungguh apa yang berguna bagimu, mohonlah pertolongan kepada Allah Azza wa Jalla dan janganlah kamu menjadi orang yang lemah. Apabila kamu tertimpa suatu kemalangan, maka janganlah kamu mengatakan: 'Seandainya tadi saya berbuat begini dan begitu, niscaya tidak akan menjadi begini dan begitu'. Tetapi katakanlah: 'Ini sudah takdir Allah dan apa yang dikehendaki-Nya pasti akan dilaksanakan-Nya. Karena sesungguhnya ungkapan kata 'law' (seandainya) akan membukakan jalan bagi godaan syetan.'

Demikian juga hadits berikut menunjukkan fungsi komunikasi untuk memengaruhi: 


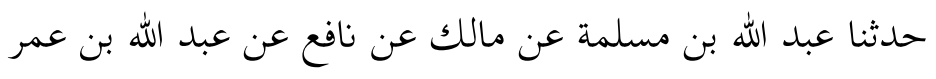

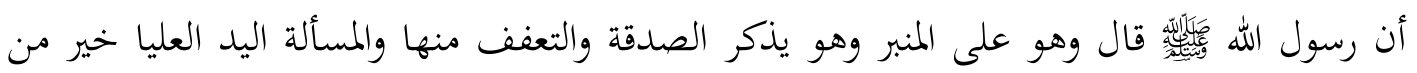

اليد السفلى واليد العليا المنفقة والسفلى السائلةقال أبو داود اختلف على أيوب عن نافع في هذا الحديث قال

عبد الوارث اليد العليا المتعففة و قال أكثرهم عن حماد بن زيد عن أيوب اليد العليا المنفقة و قال واحد عن

حماد المتعففة

Sunan Abu Daud 1405: Telah menceritakan kepada Kami Abdullah bin Maslamah dari Malik, dari Nafi' dari Abdullah bin Umar, bahwa

Rasulullah shallallahu 'alaihi wa sallam di atas mimbar bersabda dan beliau menyebutkan mengenai sedekah, menahan diri darinya, serta mengenai sikap memintaminta: "Tangan yang di atas lebih baik daripada tangan yang di bawah. Tangan yang di atas adalah yang berinfak, sedangkan tangan yang di bawah adalah yang meminta-minta."

Abu Daud berkata: telah diperselisihkan pada Ayyub dari Nafi' dalam hadits ini. Abdul Warits mengatakan: "Tangan di atas adalah yang menahan diri (dari meminta-minta)." Kebanyakan mereka mengatakan: dari Hammad bin Zaid dari Ayyub: "Tangan yang di atas adalah yang berinfak." Salah seorang dari mereka mengatakan dari Hammad: "Yaitu yang menahan diri (dari meminta-minta)." 


\section{DAFTAR PUSTAKA}

A. Joseph DeVito, Komunikasi Antarmanusia: Kuliah Dasar ed.5. Alih Bahasa Agus Maulana. Jakarta: Professional Books, 2011.

Berelson Bernard and Gary A. Steiner. 1964. Human Behavior: An Inventory of Scientific Finding. New York: Harcourt Brace Javanovich, 1964

Everett M. Rogers dan Lawrence Kincaid, Communication Nerwork: Towards a New Paradigm for Research. New York: Free Press, 1981

Haidar Daulay, Pendidikan Islam dalam Sistem Pendidikan Nasional di Indonesia, Jakarta: Prenana Media Group, 2014.

Hovland, Carl I, Social Communication. Am Phil. Soc. XCII, Dance No. 33/Catg. Stappers 1948

Jalaluddin Rakhmat. Psikologi Komunikasi. Bandung : Remaja Rosdakarya.2008.

Siagian \& Abdullah, Optimalisasi Fungsi dan Peran Pemuka pendapat di Sulawesi Selatan. Makassar: Jurnal Stimulus Universitas Muslim Indonesia, ISSN. 2088-2742, Edisi II, Juli-Desember 2011

Wiryanto, Pengantar Ilmu Komunikasi, (Jakarta: Grasindo Persada, 2004), h. 5

\section{Kitab Hadits:}

Sunan Abu Dawud No. 4031, 4318, 1405

Shahih Muslim No. 2825, 4664, 4816

Sunan Tirmidzi No. 1857, 3155

Shahih Bukhari No. 5651, 595, 4957

Musnad Ahmad No. 18410, 19240, 19241 dan 19255 